\title{
EL JUSTO MEDIO. ENSAYOS SOBRE ARTE CONTEMPORÁNEO, EDUCACIÓN Y FORMACIÓN INTEGRAL Pedro Agudelo Rendón*
}

\author{
Universidad Industrial de SANTANDER, \\ BuCARAMANGA, 20I6, II 7 P.
}

Robinson Serna Hincapié

\footnotetext{
* Cómo citar esta reseña: Serna Hincapié, R. (2022). Reseña del libro El justo medio. Ensayos sobre arte contemporáneo, educación y formación integral, de Pedro Agudelo Rendón. Estudios de Literatura Colombiana 50, pp. 197-200. DOI: https://doi. org/10.17533/udea.elc.n50a11

1 https://orcid.org/0000-0001-8978-3862 robinson.serna@udea.edu.co

Universidad de Antioquia, Colombia
}

Editores: Andrés Vergara Aguirre, Christian Benavides Martínez

Recibido: 23.08 .2021

Aprobado: 26.11.2021

Publicado: 17.01 .2022

Copyright: $@ 2022$ Estudios de Literatura Colombiana. Este es un artículo de acceso abierto distribuido bajo los términos de la Licencia Creative Commons AtribuciónNo comercial - Compartir igual 4.0 Internacional

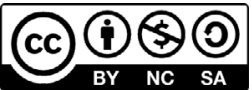

El arte es, sin lugar a dudas, una de las actividades humanas que mejor permite comprender al ser humano. Ya lo han señalado autores tan importantes como Heidegger o Gadamer, para quienes el arte es algo más que un producto objetual. La obra de arte, afirma Gadamer, dice algo, y al hacerlo pertenece al contexto del comprender. Ella dice algo, declara algo que estaba oculto, muestra aquello que pasa desapercibido en la vida cotidiana. Ella le habla a la propia autocomprensión de cada uno; es decir, cuando estamos frente a la obra de arte ella establece un diálogo, y es en este estar dispuestos a la conversación que se produce el sentido.

$\mathrm{El}$ arte, lo sabemos, tiene un papel fundamental en la formación de los sujetos, y contribuye en el desarrollo no solo de sus habilidades motrices, sino también en el despliegue de la creatividad; ayuda a afinar la percepción y la capacidad para apreciar y disfrutar (dimensión estética), pero también a aprender a ver y a analizar (dimensión y cognitiva). $\mathrm{El}$ arte aporta en la formación humanística y amplía la visión sobre la realidad, las cosas y la vida 
en general. Su fuerza está en la capacidad declarativa que le es propia, y de ahí la necesidad de repensarlo no solo desde los gestos propios del arte contemporáneo, sino también a través de prácticas pedagógicas pertinentes.

De esto habla El justo medio. Ensayos sobre arte contemporáneo, educación y formación integral de Pedro Agudelo Rendón, editado por la Dirección Cultural de la uis. El libro, un ensayo literario en su sentido más actualizado, habla sobre los problemas del arte contemporáneo, especialmente colombiano, y su relación con los procesos de formación tanto escolares como extraescolares. Con un amplio bagaje, el autor hace un recorrido desde diferentes perspectivas como la crítica de arte, la crítica literaria, la historia y la filosofía del arte, la educación y la semiótica.

El título (El justo medio) aparece solo una vez en todo el ensayo, en un sutil juego que alude, de forma subrepticia, a una idea aristotélica que soporta la necesidad de más y mejores políticas educativas y artísticas, lo cual exige la "elección del justo medio, por cuanto la justicia es la virtud ética suprema” (Agudelo Rendón, 2016, p. 110). Pero no solo el título hace de este ensayo un trabajo literario. Lo hace, también, el tema y la forma de argumentación, a través de juegos analógicos, comparaciones y metáforas. Lo hace, además, el uso estético del lenguaje, la manera de nombrar la realidad, de describir y plantear nuevas ideas sobre los procesos literarios, artísticos y educativos.

Vale la pena recordar que el ensayo literario en nuestro país ha tenido importantes figuras como Hernando Téllez o Pedro Gómez Valderrama, y los sigue teniendo, a pesar que de que recientemente un Premio Nacional de Ensayo quedara desierto, algo que no puede ser imputado a la falta de buenos ensayistas en Colombia. El libro de Pedro Agudelo Rendón es un ejemplo de una nueva generación de escritores literarios que afronta el desafío literario del ensayo. Este género, abatido para algunos por falta de una producción más prolífica, es además una expresión genuina que imbrica el pensamiento con las formas creativa y estética de la palabra.

El justo medio es una expresión estética del pensamiento que, si bien aborda temas de arte y educación, asume una postura literaria, propia de quien se arroga con compromiso sincero el oficio de escribir. No en vano Wilson Gómez, Ariel Castillo y Alberto Abello afirman que "el autor, dueño de un gran bagaje — sin ninguna pedantería - trasciende el saber específico del arte, y en su aproximación se propone abarcar los contextos históricos, políticos, culturales e ideológicos, con una mirada interdisciplinaria que haga de la apreciación artística una forma de abordar con sen- 
sibilidad y lucidez la realidad, desde una perspectiva democrática, nada temerosa de los errores que permiten crecer”. Recodemos que el libro de Agudelo Rendón fue reconocido con el Premio de Ensayo Literario en 2016, entregado por la Universidad Industrial de Santander.

Algunas de las ideas desarrolladas en El justo medio tendrían una orientación todavía más amplia en su otro libro, América pintoresca, con el cual el autor obtiene el Premio Literario Casa de las Américas en 2017. Es preciso señalar, entonces, que no se trata de un escritor que ordena sus ideas en un discurso de tipo académico, sino de un escritor que asume en el lenguaje literario una forma de asumir la vida. El libro editado por la uis es un buen ejemplo de ello, toda vez que reinterpreta el concepto de arte y lo hace desde una visión semiótica, literaria y sensible. El texto sostiene, entre otras cosas, que el arte tiene un poder transformador capaz de reordenar la existencia humana: "devela los quiebres de la razón, los matices de los sentimientos, las formas de percepción, el proceder en el razonamiento” (p. 16). En el primer capítulo, y a través de la metáfora literaria y filosófica de la "esfera pública", presenta una reflexión sobre los poderes transformadores del arte a partir de la obra del artista Fredy Alzate, de su poder vindicante con lo urbano y su capacidad de democratizar aquello que de cuño le pertenece a los ciudadanos: la capacidad de reflexionar. El segundo capítulo pone en relación el arte con la literatura, la palabra con la imagen y el ícono con el símbolo a través de la propuesta visual de la artista Johana Calle. Muestra los valores plásticos de su obra, pero también la manera en que su trabajo parece bordear los problemas más profundos de la sociedad colombiana.

Los capítulos tres y cuatro se centran en la función del arte, en su dimensión pragmática tanto en el devenir de los sujetos como en los procesos normatizados por la educación. Primero, toma algunas ideas de la filosofía de Charles Sanders Peirce para mostrar la necesidad de replantear la manera en que se asume el arte en el sistema educativo actual; después, conceptualiza y reflexiona sobre la Didáctica de la Educación Artística desde una perspectiva semiótica, y muestra su capacidad para reinventar los modos en que se puede asumir la formación integral. El carácter bifronte del texto (el libro está dividido en dos partes) es otro indicio del juego literario en su estructura. Allí, sin duda, hay 'otro’ justo medio: la relación dinámica entre la lúdica y la razón. En la primera parte, que comprende los capítulos uno y dos, hay un juego, una visión más literaria de lo que es el arte en la actualidad; en la segunda, que 
corresponde a los capítulos tres y cuatro, hay un trabajo más sistemático, de reflexión y crítica. Otro rostro aparece en las constantes alusiones literarias y artísticas: el de la ecfrasis literaria, esa figura retórica que implica la descripción nítida de un objeto.

Puede decirse que El justo medio es un libro cuyo estilo es directo, al tiempo que intrincado y tejido por las mismas tramas que unen al arte con la educación y a la literatura con las artes visuales. Es razonado, por cuanto un ensayo procura seguir una idea que debe ser argumentada; pero al tiempo es poético y estético, pues asume las palabras como una apuesta creativa y literaria que reformulan un lugar a la visión literaria del pensamiento. El libro es una estocada. Es como si las palabras nos dejaran a la deriva y solo nos quedaran las imágenes, y entonces, destinados al naufragio, esperáramos incautos a que Wang-Fô nos rescate con sus pinceles. 